\title{
A Brief Analysis on the Causes of the Chinese Nation's Strong Feelings toward their Home and Country
}

\author{
Hong Wang* \\ Heilongjiang Political and Legal Management Cadre Institute, China \\ *Corresponding author: Hong Wang, hongwang1976@163.com
}

\begin{abstract}
The love for our children as well as the love for our country and people" are the common emotions of all human beings. The Chinese nation's feelings toward their relatives, hometown, and country are immensely deep and strong that they have surpassed all other nations. This article analyzed the causes of the Chinese nation's strong feelings toward their home and country based on China's development history and geopolitics.
\end{abstract}

Keywords: Chinese nation's feelings; Home and country; Causes

Publication date: June 2021; Online publication: June 30, 2021

Any nation with a long history in the process of development will inevitably encounter some existential threats in which some of these come from the nature, external nationality, the country itself, or internal conflicts. Certainly, only nations with unanimity, bravery, as well as strong home and country feelings would surpass the long history of iron and blood for survival and development opportunities. The Chinese nation is the most typical representation. The causes of the Chinese nation's strong feelings toward their home and country have its historical significance.

First of all, the Chinese nation is one of the first three nations to develop agriculture.

Around the world, there were three nations that invented agriculture the earliest which were the ancient Egyptians, the Chinese, and the Jewish nation. This can be shown from the development sequence of calendars in which agricultural civilization cannot be deemed as a separate entity. These nations were the earliest countries to develop the calendar because the crucial development of agriculture is based on the calculation of agricultural time. If the agricultural time is mistaken, the effort in that year might just be in vain. This is an inevitable phenomenon of the agricultural culture. In ancient Egypt, along the Nile were crops for both rice and wheat which were located far from each other. The pharaoh, in ancient Egypt had sacred duties in which one of the most important is to accurately predict water from the Nile. When floods came, farmers would grow rice according to the forecast; however, if the pharaoh's prediction was wrong, that pharaoh will be executed. With that, the first solar calendar in human history was created. Agriculture in China has been developing since the Neolithic settlements. After the Warring States period, an intensive cultivation system among small farmers was gradually developed to about ten thousand at present. This does not only prove that there have been many archaeological achievements but also gave birth to the world's oldest and most matured calendar in which it is still used among farmers today. It is remarkably consistent with the seasonal cycle, and it is known as the lunar calendar or the ancient calendar. Finally, the Jews, who first lived in Mesopotamia, between the Euphrates and the Tigris River, and what is now Jerusalem also invented agriculture very early. The Jewish calendar is more than 3800 years old. Among 
these three nations, the ancient Egyptian race, state, and culture were interrupted. Scientists used DNA tests to prove that $99 \%$ of Egyptians today are not the offspring of pure Egyptians but they are immigrants from Africa. Hence, their affection for the country may not be deep. Jews on the other hand initially lived with the Arabs, however due to serious desertification, they collectively retreated to Egypt and stayed there for hundreds of years. After being chased away by a new pharaoh, they went back to Jerusalem but the land was occupied by the Arabs. Hence, they were unable to go "home" and wandered around for thousands of years. Even though they have no home or country, their religion is still persistent. Until 1948, after the end of the second world war and with the involvement of the Anglo-American relations, a plot of land in Jerusalem was laid down for them. However, they may not have deep affections or impressions for the country. This was not the case for the Chinese nation. As an ancient nation, the early invention of agriculture indicated that their ancestors have settled down earlier. Moreover, the nation's race and culture have never been interrupted, hence, they have deep affection for their land and sustained a lasting and close relationship with the surrounding environment. From this, a geographical relationship (village) has been formed. Unlike the nomads who ride their horses everywhere and lived in search of water and grass while having little affection for the land and surrounding environment, China is of great importance to its fellow villagers. Is it possible to run an agricultural nation, take responsibility for the land that have been intensively cultivated, and be grounded and strong like a house that has been built? For thousands of years, the Chinese nation's ancestors have lived and procreated in China, implying that the Chinese nation has strong feelings toward their home and country.

Secondly, the Chinese nation is one of the earliest integrated nations.

Ethnic fusions to form deep kinship relationships (family) via intermarriage begin as early as 7000 years ago with the Yellow Emperor, surname Ji and Yan Emperor, surname Jiang. The Chinese people have acknowledged the descendants of the Yellow Emperor, and these were summarized in the Shiji sovereigns of Sima Qian and biographic sketches since the Warring States period to the early Western Han Dynasty. Many scholars had research the achievements in this period. In the warring states, ancestors of the Chinese nation from thousands of years ago had mutual confluences including marriages but blood was shed on these confluences yet cultural integration started at a very early stage and the fusion never stopped. The early integration is of great significance as a unified language is formed, as well as the establishment of common cultural psychology and value orientation. Even if an individual's family name is Zhang and another owns the family name of Wang, both are from the same hometown but even if they are not, they are both Chinese.

Thirdly, the Chinese nation has been in a state of unity for a long time.

Europe has been long divided while China has been united. As understood, the Huns brought down the Roman empire and got caught up in a division of Europe. Europe was then fragmented with conflict all year round. Geoffrey Parker described in "The Cambridge history" that between the 14th and 15th centuries, Britain and France fought for 100 years and between the 16th and 17th centuries, there were more wars than any other period in the history of Europe. During the 16th century there were only 25 years of peace in Europe, and in the 17th century there were only 21 years of peace; meaning to say that 154 years out of 200 years were in war. Yet when discussing about Chinese history, people speak about how brutal it is. In the long agricultural era, the cruel and brutal history of Europe in fighting to drag down the production has caused low productivity levels, scarce food and clothing, and poor epidemic preventions where in the $14^{\text {th }}$ century, the "black death" swept across Europe and in just six years, 25 million lives were claimed which accounted for one-third of Europe. In the face of long sufferings, Europeans had no recourse to this world, but to the afterlife, thus bringing forth strong Christian and Jewish beliefs which eventually gave rise to Eastern Orthodoxy, Protestantism, and Islam which have been influential ever since. In Marx's Critique of Hegel's Philosophy of Law, the suffering in religion is not only the expression of the suffering in reality 
but also, the protest against it. "Religion is the sigh of the oppressed, the heart of the heartless world, just as it is the soul of a soulless system in which religion is the opium of the people." This sentence is absolutely right. Religion is indeed in direct proportion to suffering. However, unlike the situation in Europe, China has been a unified country for a long time. In $221 \mathrm{BC}$, China has established a unified system due to the lack of "unification" of peer competitors. Definitely, China would have had splits and conflicts which appeared in temporary religious conflicts such as "how many number crunchers in four hundred and eighty temples, in the misty rain." However, in their minds, these people had insisted that China should be unified and hence, they finally united again. Appreciating China's unity, peace, and stability throughout history allowed the Chinese's "home country" to be a hope in the world and passed down from generation to generation. As a result, Confucianism with humanistic nature subdued the competition including religion with its ideological trends; hence, "national feelings" were formed and introduced.

Finally, ancient sages and individuals with lofty ideals further strengthened the Chinese's feelings toward their home and country.

Sages across the world offered an example with their noble personality in further enhancing the cultural psychology of the Chinese people. There was a wise king among them with sound military commanders, effective civil servants, and intellectual people which struggled to death for the sake of the country. This influenced their children and grandchildren. Hence, in the same way, the Chinese nation's children and grandchildren have also been inspired by their ancestors to learn from them in the country's struggle for life and thereafter, inspiring the next generation. The Chinese nations' feelings toward their homes are beautiful and moving. In the Tang or Ci poetry, the matter of love or war should not be missed however, the first subject to be emphasized on is undoubtedly in regard to missing home or relatives and the concept of motherland which is almost without exception, the most beautiful.

In the tens of thousands of years, the Chinese nation's history is an asset and not a negative equity. Such feelings sanction together the hearts and minds of the Chinese nation, concede in the formation of China's "community of common destiny," and eventually, this large family comprising of the Chinese nation would entail progress arm in arm.

\section{Funding}

Phase results of Institute of College-level Project (Project No. 202013) by Longjiang Provincial Political and Legal Management Cadre Institute.

\section{Disclosure statement}

The author declares no conflict of interest.

\section{References}

[1] Shi S, 2015, Five thousand years or ten thousand years, Guangxi Normal University Press.

[2] Liu Z, 2019, Nationalism: belief of Chinese people, Learning Press.

[3] Parker G, 2001, The Cambridge war history, Jilin People's Publishing House.

[4] $\mathrm{Wu} \mathrm{W,} \mathrm{2011,} \mathrm{On} \mathrm{the} \mathrm{believing} \mathrm{dimension} \mathrm{of} \mathrm{the} \mathrm{cultural} \mathrm{consciousness} \mathrm{of} \mathrm{the} \mathrm{Chinese} \mathrm{nation.} \mathrm{Journal}$ of the University of Jinan, 6. 